\title{
Persepsi Sakit dan Pemahaman Penggunaan Obat Rasional (POR) di Kota Denpasar
}

\author{
I Putu Tangkas Suwantara ${ }^{1 *}$, Fitria Megawati ${ }^{1}$, Ni Putu Wintariani ${ }^{2}$, Putu Eka \\ Arimbawa $^{2}$ \\ ${ }^{1}$ Fakultas Farmasi, Universitas Mahasaraswati, Indonesia \\ ${ }^{2}$ Prodi Farmasi Klinis, Universitas Bali Internasional, Indonesia \\ *Korespondensi: tangkas.suwantara@unmas.ac.id
}

\begin{tabular}{|c|c|}
\hline Info Artikel & Abstrak \\
\hline $\begin{array}{c}\text { Diterima } 30 \text { April } \\
2021\end{array}$ & $\begin{array}{l}\text { Persepsi akan memunculkan perilaku sakit untuk melakukan pengobatan } \\
\text { sendiri, sehingga dapat menyebabkan pemahaman penggunaan obat } \\
\text { menjadi tidak rasional. Tujuan penelitian ini untuk mengetahui hubungan } \\
\text { persepsi sakit dengan pemahaman penggunaan obat rasional di Kota }\end{array}$ \\
\hline $\begin{array}{l}\text { Disetujui } 14 \text { Mei } \\
\qquad 2021\end{array}$ & $\begin{array}{l}\text { Denpasar. Penelitian ini memakai desain survei cross-sectional, dengan } \\
\text { sampel sebesar 97. Pengumpulan data dilakukan pada bulan Januari- }\end{array}$ \\
\hline $\begin{array}{l}\text { Dipublikasikan } 17 \\
\text { Mei } 2021\end{array}$ & $\begin{array}{l}\text { memakai uji binary logistic. Hasil penelitian menunjukkan terdapat } \\
\text { hubungan yang signifikan antara persepsi sakit dengan pemahamam }\end{array}$ \\
\hline $\begin{array}{l}\text { Keywords: } \\
\text { Persepsi; } \\
\text { Pengobatan; POR; } \\
\text { Sakit }\end{array}$ & $\begin{array}{l}\text { pemahaman penggunaan obat rasional }(P<0.05) \text {. Persepsi sakit mengenai } \\
\text { kondisi tubuh (36.4\%) atau keadaan rasa sakit }(32.4 \%) \text { memiliki nilai } \\
\text { paling besar, sedangkan pemahamm } P O R \text { paling tinggi kesalahan adalah } \\
\text { mengenai obat batuk, obat panas, obat diare tidak perlu diminum sampai } \\
\text { habis jika gejalanya sudah hilang }(50.5 \%) \text { dan semua obat diminum }\end{array}$ \\
\hline $\begin{array}{l}\text { (C) } 2019 \text { Universitas } \\
\text { Muhammadiyah } \\
\text { Buton } \\
\text { Under the license } \\
\text { CC BY-SA } 4.0 \\
\text { (c) (P) (-) }\end{array}$ & $\begin{array}{l}\text { setelah makan (26.8\%). Kondisi tubuh terutama dalam hal tidak dapat } \\
\text { melakukan aktivitas dan keluhan rasa sakit akan menyebabkan } \\
\text { masyarakat mencari suatu pengobatan, sehingga hal ini dapat } \\
\text { mengakibatkan pemahaman mengenai POR terutama mengenai gejala } \\
\text { simtomatis dan penggunaan obat. Oleh karena itu, perlu pemberian } \\
\text { informasi yang tepat tentang obat ketika masyarakat mencari pengobatan } \\
\text { untuk mengatasi keluhan yang dirasakan. }\end{array}$ \\
\hline & 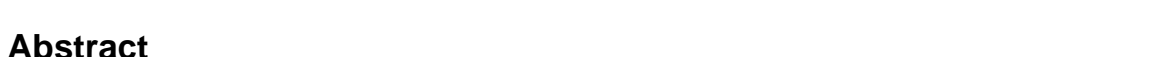 \\
\hline & $\begin{array}{l}\text { Perception will lead to illness behavior in taking action by doing self- } \\
\text { medication to lead to an irrational understanding of drug use. This study } \\
\text { aimed to determine the relationship between the perception of pain and the } \\
\text { knowledge of rational drug use in Denpasar City. This study used a cross- } \\
\text { sectional survey design. The number of samples used was } 97 \text {. Data were } \\
\text { collected from January-February } 2020 \text { in Denpasar City using a } \\
\text { questionnaire. Data were analyzed using the binary logistic test. The } \\
\text { results showed a significant relationship between the perception of pain } \\
\text { and the understanding of rational drug use ( } P \text { - }<.05) \text {. The perception of } \\
\text { discomfort regarding the body's condition (36.4\%) or the state of pain } \\
\text { (32.4\%) had the most outstanding value. The understanding of POR with } \\
\text { the highest error was regarding cough medicine, hot medicine, diarrhea } \\
\text { medicine that does not need to be drunk until it runs out if the symptoms } \\
\text { have disappeared (50.5\%) and taken after meals (26.8\%). The condition of }\end{array}$ \\
\hline
\end{tabular}


the body, especially in terms of inability to carry out activities and complaints of pain, will cause people to seek treatment, leading to an understanding of POR, especially regarding symptomatic symptoms and drug use. Therefore, it is necessary to provide accurate information about drugs when people seek treatment to overcome their perceived complaints.

\section{Pendahuluan}

Persepsi merupakan stimulus yang berasal dari lingkungan individu itu berada yang merupakan hasil dari proses belajar dan pengalaman. Salah satu hasil persepsi proses tersebut adalah persepsi mengenai sakit. Sakit disebabkan ketidakseimbangan fungsi normal tubuh manusia, sehingga menyebabkan kemampuan untuk melakukan kegiatan menjadi menurun (Asmadi, 2008). Pada saat sakit, perilaku yang muncul adalah melakukan pengobatan sendiri, dan berakibat penggunaan obat menjadi tidak sesuai.

Penggunaan obat di masyarakat untuk kesembuhan dari penyakit sangat tinggi. Hasil riset kesehatan dasar menunjukkan bahwa $35,2 \%$ rumah tangga menyimpan obat untuk swamedikasi dan $86,1 \%$ merupakan obat antibiotik (Badan Penelitian dan Pengembangan Kesehatan, 2013). Tingginya penggunaan obat di masyarakat akan memunculkan permasalahan mengenai obat. Salah satunya adalah penggunaan obat tidak rasional. Hasil penelitian menyatakan penggunaan obat tidak rasional di kota Denpasar mencapai lebih dari $50 \%$ di masyarakat (WHO, 2002). Selain itu juga penelitian lain menyatakan persentase kasus penyalahgunaan obat mencapai 42,7\% (Hashemi et al., 2013). Hasil ini juga didkung oleh penenlitian yang menyatakan tingkat penggunaan obat tidak rasional di Kota Denpasar mencapai 44.3\% (Arimbawa, 2017).

Pemahaman penggunaan obat secara rasional (POR) dipengaruhi oleh persepsi sakit seseorang. Berdasarkan hasil penelitian persepsi sakit masyarakat terhadap obat masih rendah, hal ini karena hanya sebanyak kurang dari $40 \%$ responden memilih obat berdasarkan persepsi sakit (Amisim et al., 2020). Hasil serupa juga menunjukkan hanya $50 \%$ responden menunjukan persepsi yang merupakan hal yang digunakan pada pemilihan obat (Ruksakulpiwat et al., 2020). Pemilihan obat berdasarkan persepsi sakit akan menyebabkan pemakian obat tidak sesuai dengan indikasi dan dapat menyebabkan penggunaan obat menjadi tidak rasional. Berdasarkan permasalahan tersebut, persepsi sakit dan pemahaman POR berhubungan. Novelty penelitian ini berbeda dengan riset sebelumnya, yaitu lebih spesifik menggali POR melalui persepsi sakit dan merupakan penambahan hal yang mempengaruhi POR dari penelitian sebelumnya (Arimbawa \& Adi, 2019). Urgensi penelitian ini dilakukan mengingat semakin tingginya kesalahan pengobatan di masyarakat, termasuk di Kota Denpasar. Tujuan penelitian ini untuk melihat hubungan persepsi sakit dengan pemahaman penggunaan obat rasional di Kota Denpasar.

\section{Metode Penelitian}

Penelitian ini menggunakan rancangan desain cross-sectional. Penelitian sudah memperoleh ijin ethical clearance No.001/IIK BALI/EC/XII/2019 yang dikeluarkan oleh Institut IImu Kesehatan Medika Persada Bali. Peneliti 
menanyakan secara langsung dengan menggunakan kuesioner kepada masyarakat yang dilakukan bulan Januari-Februari 2020. Metode pengambilan sampel menggunakan purposive sampling. Perhitungan sampel untuk penelitian ini menggunakan perhitungan berdasarkan populasi Kota Denpasar.

$$
\begin{aligned}
& n=\frac{N Z^{2} 1-\alpha / 2 P(1-P)}{N d^{2}+\mathrm{Z} 21-\alpha / 2 P(1-P)} \\
& n=\frac{(788.589)(1,96)^{2}(0,50)(1-0,50)}{(788.589)(0,1)^{2}+(1,96) 2(0,50)(1-0,50)} \\
& n=97 \text { Sampel }
\end{aligned}
$$

Keterangan: $\mathrm{n}=$ Sampel, $\mathrm{P}=$ Proporsi kejadian. Jika tidak diketahui maka ditetapkan $50 \%(0,50): \mathrm{n}=$ sar populasi $788.589, d=$ Limit error atau presisi absolute $0,1, \mathrm{Z}^{2}{ }_{1-\alpha / 2}=$ Criajaı nepercayaan 1,96 . Sampel yang digunakan dalam penelitian ini adalah 96.

Kriteria inklusi penelitian adalah masyarakat usia 18-60 tahun, dan bertempat tinggal di Kota Denpasar. Kriteria eksklusi penelitian ini adalah masyarakat yang bekerja sebagai tenaga kesehatan. Kuesioner persepsi sakit dibuat berdasarkan beberapa jurnal tentang persepsi sakit (Lorensia et al., 2017), (Amisim et al., 2020), (Nofiyanto et al., 2014), (Agustina, 2019) dan Focus Grup Discussion (FGD) dengan beberapa dokter dan apoteker di Kota Denpasar. Focus Grup Discussion (FGD) dilakukan selama dua minggu. Pelaksanaan FGD dengan beberapa dokter dan apoteker dilakukan secara kualitatif yang bertujuan menvalidasi kontekstual mengenai pertanyaan kuesioner mengenai persepsi sakit selama lima hari. Saran dan perbaikan hasil kontekstual kuesioner dilakukan selama dua hari dan dijadikan sebagai dasar evaluasi kuesioner. Hasil revisi kemudian diserahkan kembali kepada dokter dan apoteker untuk mengecek perbaikan kuesioner selama tujuh hari dan dilanjutkan secara kuantitatif untuk pengujian realibilitas-validitas. Uji realibilitas-validitas menggunakan 40 sampel. Kuesioner yang diberikan kepada responden terdiri dari 11 pernyataan tentang persepsi sakit. Hasil tes dikatakan realibilitas-validitas apabila nilai tabel $\mathrm{R}>0.312$ dan Cronbach's Alpha>0.60. Hasil uji validitas-realibilitas kuesioner persepsi sakit (11 Pertanyaan) menunjukkan nilai validitas terendah-tertinggi adalah $0.35-0.71$, dan nilai realibilitas 0.743 . Kuesioner pemahaman penggunaan obat rasional mengadopsi penelitian sebelumnya mengenai POR (Arimbawa \& Adi, 2019). Metode analisis data menggunakan uji binary logistic.

\section{Hasil dan Pembahasan}

\subsection{Hasil}

Hasil karakteristik dapat dilihat pada tabel 1. Karakteristik jenis kelamin lakilaki (46.4\%). lebih sedikit dibandingkan dengan perempuan (53.6\%). Karakteristik pernikahan tidak menikah (39.2\%) masih sedikit dibandingkan dengan yang menikah (60.8\%). Pendidikan masyarakat Tidak Sekolah/SD/SMP/SMA (62.9\%) lebih banyak dibandingkan dengan D3/D4/S1/S2 (37.1\%). Pekerjaan di masyarakat paling banyak adalah karyawan swasta $(63.9 \%)$, pengusaha $(16.3 \%)$, 
tidak bekerja (10.3\%) dan PNS (8.2\%). Umur paling sedikit adalah Lansia (13.4\%), Dewasa Awal (17.3\%), Dewasa Akhir (23.7\%) dan Remaja (82.7\%).

Tabel 1. Distribusi Frekuensi Karakteristik Responden

\begin{tabular}{|c|c|c|c|c|c|}
\hline \multicolumn{3}{|c|}{ Karakteristik Sampel } & \multicolumn{2}{|r|}{$\mathbf{F}$} & $\%$ \\
\hline \multicolumn{6}{|c|}{ Jenis Kelamin } \\
\hline \multicolumn{3}{|c|}{ Perempuan } & \multicolumn{2}{|r|}{52} & 53.6 \\
\hline \multicolumn{3}{|c|}{ Laki-laki } & \multicolumn{2}{|r|}{45} & 46.4 \\
\hline \multicolumn{6}{|c|}{ Status Pernikahan } \\
\hline \multicolumn{3}{|c|}{ Belum Menikah } & \multicolumn{2}{|r|}{38} & 39.2 \\
\hline \multicolumn{2}{|c|}{ Menikah } & \multicolumn{3}{|r|}{59} & 60.8 \\
\hline \multicolumn{6}{|c|}{ Pendidikan } \\
\hline \multirow{2}{*}{\multicolumn{2}{|c|}{$\begin{array}{l}\text { Tidak Sekolah/SD/SMP/SMA } \\
\text { D3/D4/S1/S2 }\end{array}$}} & \multirow{2}{*}{\multicolumn{3}{|c|}{$\begin{array}{l}61 \\
36\end{array}$}} & 62.9 \\
\hline & & & & & 37.1 \\
\hline \multicolumn{6}{|c|}{ Pekerjaan } \\
\hline \multirow{2}{*}{\multicolumn{2}{|c|}{$\begin{array}{l}\text { Tidak Bekerja } \\
\text { Karvawan Swasta }\end{array}$}} & & 10.3 \\
\hline & & \multirow{2}{*}{\multicolumn{3}{|c|}{$\begin{array}{l}62 \\
17\end{array}$}} & 63.9 \\
\hline \multicolumn{2}{|r|}{ Penqusaha } & & & & 16.3 \\
\hline \multicolumn{2}{|c|}{ PNS } & \multicolumn{3}{|r|}{8} & 8.2 \\
\hline \multicolumn{6}{|c|}{ Umur } \\
\hline \multirow{4}{*}{\multicolumn{2}{|c|}{$\begin{array}{l}\text { Remaja } \\
\text { Dewasa Awal } \\
\text { Dewasa Akhir } \\
\text { Lansia }\end{array}$}} & \multicolumn{3}{|r|}{86} & 82.7 \\
\hline & & \multicolumn{3}{|r|}{18} & 17.3 \\
\hline & & \multicolumn{3}{|r|}{23} & 23.7 \\
\hline & & \multicolumn{3}{|r|}{13} & 13.4 \\
\hline \multicolumn{6}{|c|}{$\begin{array}{l}\text { Hasil rekapitulasi kuesioner persepsi sakit ditunjukkan pada tabel } 2 \text {. Persepsi } \\
\text { sakit poin setuju paling besar adalah mengenai kondisi tubuh }(36.4 \%) \text { dan poin } \\
\text { tidak setuju adalah keadaan rasa sakit (32.4\%) memiliki nilai paling besar. }\end{array}$} \\
\hline \multicolumn{6}{|c|}{ Tabel 2. Distribusi Jawaban Responden Pada Kuesioner Persepsi Sakit } \\
\hline No & Pernyataan & & Respon & & \\
\hline & & Tidak Setuju & Kurang Setuju & Cukup Setuju & Setuju \\
\hline 1 & $\begin{array}{l}\text { Jika saya mengeluh/ } \\
\text { sakit saya akan menasa } \\
\text { pengobatan }\end{array}$ & 14.3 & 22.9 & 27.6 & 35.2 \\
\hline 2 & $\begin{array}{l}\text { Ketika mengalami sakit, saya } \\
\text { tidak dapat melakukan aktivitas }\end{array}$ & 17.2 & 33.4 & 15.3 & 34.1 \\
\hline 3 & $\begin{array}{l}\text { Jika saya sudah tidak dapat } \\
\text { melakukan pekerjaan sehari- } \\
\text { hari, akan lebih baik saya pergi } \\
\text { ke instansi kesehatan untuk } \\
\text { memeriksakan diri }\end{array}$ & 20.8 & 29.5 & 13.3 & 36.4 \\
\hline 4 & $\begin{array}{l}\text { Saya beranggapan jika saya } \\
\text { sakit tanpa berobat/ pergi ke } \\
\text { dokter gejala yang saya derita } \\
\text { akan lenyap dengan sendirinya }\end{array}$ & 22.9 & 38.1 & 30.5 & 8.6 \\
\hline 5 & $\begin{array}{l}\text { Saya akan memperioritaskan } \\
\text { kesembuhan saya jika sakit } \\
\text { dibandingkan dengan yang lain }\end{array}$ & 8.8 & 30.5 & 28.6 & 32.1 \\
\hline 6 & $\begin{array}{l}\text { Ketika sakit, saya tidak berbuat } \\
\text { apa- apa (tidak berobat/ pergi ke } \\
\text { dokter) karena kondisi sakit saya } \\
\text { tidak mengganggu kegiatan/ } \\
\text { pekerjaan saya sehari-hari }\end{array}$ & 20 & 33.3 & 26.7 & 20 \\
\hline 7 & $\begin{array}{l}\text { Bila ada keluarga yang } \\
\text { mengalami sakit, maka akan }\end{array}$ & 12.1 & 15.1 & 37.1 & 35.7 \\
\hline
\end{tabular}




\begin{tabular}{clcccc}
\hline \multicolumn{2}{l}{$\begin{array}{l}\text { sangat mempengaruhi aktivitas } \\
\text { keluarga }\end{array}$} & & & & \\
\hline 8 & $\begin{array}{l}\text { Menurut saya, keluhan rasa sakit } \\
\text { yang dirasakan seseorang pasti } \\
\text { sama }\end{array}$ & 32.4 & 54.3 & 6.65 & 6.65 \\
\hline 9 & $\begin{array}{l}\text { Saya akan berusaha } \\
\text { memulihkan tubuh saya ketika } \\
\text { tidak sehat karena flu }\end{array}$ & 13.4 & 24.8 & 25.8 & 36 \\
\hline 10 & $\begin{array}{l}\text { Ketika mengalami rasa sakit, } \\
\text { emosi saya menjadi tidak stabil }\end{array}$ & 19 & 34.3 & 27.6 & 19 \\
\hline 11 & $\begin{array}{l}\text { Pergi instansi kesehatan tidak } \\
\text { akan memberikan hasil yang } \\
\text { lebih baik ketika saya sakit }\end{array}$ & 32.4 & 47.6 & 15.2 & 4.8 \\
\hline
\end{tabular}

Hasil rekapitulasi kuesioner pemahaman POR ditunjukkan pada tabel 3. Masyarakat paling paham dalam penggunaan obat harus menyesuaikan dengan kondisi pasien (93.8\%), dan pasien tidak akan merahasiakan alergi obat yang dimiliki (90.7). Nilai pemahaman POR yang salah di masyarakat mengenai obat batuk, obat panas, obat diare tidak perlu diminum sampai habis jika gejalanya sudah hilang (50.5\%) dan semua obat diminum setelah makan (26.8\%). Masyarakat Kota Denpasar untuk nilai tidak tahu mengenai pemahaman POR tentang obat generic memiliki efek yang sama dengan obat yang paten walaupun harganya berbeda paing tinggi (30.9\%).

Tabel 3. Rekapitulasi Kuesioner Pemahaman POR

\begin{tabular}{|c|c|c|c|c|}
\hline \multirow{2}{*}{\multicolumn{2}{|c|}{ Pemahaman Penggunaan Obat Rasional }} & \multicolumn{3}{|c|}{ Respon \% } \\
\hline & & Tidak & Tidak Tahu & Ya \\
\hline 1 & $\begin{array}{l}\text { Apakah sebelum memilih obat anda harus } \\
\text { mengkosultasikan penyakit lain yang anda } \\
\text { derita (Penyakit jantung, diabetes, dll) }\end{array}$ & 5.2 & 8.2 & $86.6^{*}$ \\
\hline 2 & $\begin{array}{l}\text { Pemilihan obat harus menyesuaikan dengan } \\
\text { kondisi pasien (hamil, menyusui, usia,dll) }\end{array}$ & 1 & 5.2 & $93.8^{*}$ \\
\hline 3 & $\begin{array}{l}\text { Indikasi obat merupakan kegunaan dari suatu } \\
\text { obat }\end{array}$ & 5.2 & 13.4 & $81.4^{*}$ \\
\hline 4 & $\begin{array}{l}\text { Apabila memiliki alergi obat saya akan } \\
\text { merahasiakanya }\end{array}$ & $90.7^{*}$ & 84.1 & 5.2 \\
\hline 5 & $\begin{array}{l}\text { Saya Memberikan informasi penggunaan obat } \\
\text { lain sebelum membeli obat }\end{array}$ & 5.2 & 13.4 & $81.4^{*}$ \\
\hline 6 & Semua Obat diminum sebaiknya setelah makan & $53.6^{*}$ & 19.6 & 26.8 \\
\hline 7 & $\begin{array}{l}\text { Obat yang diminum } 3 \times 1 \text { tablet diminum tiap } 8 \\
\text { jam }\end{array}$ & 14.4 & 23.7 & $61.9^{*}$ \\
\hline 8 & $\begin{array}{l}\text { obat-obat antibiotika bisa di simpan apabila } \\
\text { gejala penyakit sudah tidak ada }\end{array}$ & $58.8^{*}$ & 26.8 & 14.4 \\
\hline 9 & Dosis obat yang diminum sama setiap orang & $82.5^{*}$ & 14.4 & 3.1 \\
\hline 10 & $\begin{array}{l}\text { Antibiotik dapat digunakan untuk mengobati } \\
\text { infeksi virus }\end{array}$ & $68^{*}$ & 20.6 & 11.3 \\
\hline 11 & $\begin{array}{l}\text { Obat yang kandungan sama merkna dan harga } \\
\text { berbeda memiliiki efek yang berbeda }\end{array}$ & $34^{*}$ & 26.8 & 39.2 \\
\hline 12 & $\begin{array}{l}\text { obat batuk, obat panas, obat diare tidak perlu } \\
\text { diminum sampai habis jika gejalanya sudah } \\
\text { hilang }\end{array}$ & 50.5 & 13.4 & $36.1^{*}$ \\
\hline 13 & $\begin{array}{l}\text { Jumlah obat yang dibeli menyesuaikan dengan } \\
\text { lama minum obat }\end{array}$ & 17.5 & 28.9 & $53.6^{*}$ \\
\hline 14 & $\begin{array}{l}\text { Obat generic memiliki efek yang sama dengan } \\
\text { obat yang paten walaupun harganya berbeda }\end{array}$ & 18.6 & 330.9 & $50.5^{*}$ \\
\hline 15 & $\begin{array}{l}\text { Saya akan memilih obat generik yang harganya } \\
\text { lebih murah dibandingkan dengan obat paten }\end{array}$ & 14.4 & 13.4 & $77.3^{*}$ \\
\hline
\end{tabular}


apabila uang yang punya tidak cukup untuk

membeli obat paten

*Jawaban benar

Analisis uji binary logistic ditunjukkan pada tabel 4. Hasil uji diperoleh tidak signifikan mengenai karakteristik sosiodemografi masyarakat kota Denpasar tentang jenis kelamin, pekerjaan, pendidikan, status pernikahan, penghasilan dan umur dengan pemahaman POR $(P>0.05)$. Hubungan persepsi sakit memberikan nilai yang signifikan dengan pemahaman POR $(P<0.05)$.

Tabel 4. Uji binary logistic persepsi sakit dan pemahaman (POR)

Karakteristik sosiodemografi dan

Persepsi sakit

Jenis Kelamin

Pekerjaan

Pendidikan

Status Pernikahan

Penghasilan

Umur

Persepsi sakit
OR

$95 \% \mathrm{Cl}$

Batas Batas Bawah Atas

$\begin{array}{lll}1.09 & 0.46 & 2.55\end{array}$

3.08

0.69

0.86

0.90

1.02

2.17 0.46

2.55

0.26

0.27

0.32

0.62

1.85

2.72

2.54

0.35

1.88

0.87

$P$

\subsection{Pembahasan}

Hasil penelitian menunjukkan terdapat hubungan yang signifikan antara persepsi sakit dengan pemahaman POR. Hasil penelitian menunjukkan persepsi sakit memberikan pengaruh sebesar 2.17 kali terhadap pemahaman POR. Persepsi sakit mengenai kondisi tubuh atau keadaan rasa sakit dapat mempengaruhi pemahamam POR tentang penggunaan obat untuk gejala simtomatis dan penguunaan obat. Hal ini disebabkan persepsi sakit pada masyarakat menggunakan obat sesuai dengan pengalaman atau emosi dan mencari pengobatan (pelayanan kesehatan) setelah tingkat sakit menjadi lebih buruk. Hal ini didukung oleh penelitian yang menunjukkan persepsi akan mempengaruhi emosi seperti perasaan marah, cemas, dan depresi, sehingga akan dampat mengakibatkan perbedaan penggunaan obat (Miyazaki et al., 2018). Hasil penelitian serupa juga menyatakan sebagian besar responden percaya persepsi sakit bisa diatasi dengan melakukan pengobatan sendiri (Shah et al., 2021).

Persepsi sakit mengenai kondisi tubuh terutama dalam hal tidak dapat melakukan aktivitas atau terkena batuk,flu, dan pilek membuat masyarakat untuk mencari pengobatan. Variabel persepsi sakit sebagian besar setuju dengan pernyataan jika tidak sehat seperti flu-pilek-batuk, secepat mungkin mencari cara untuk memulihkan kondisi tubuh untuk aktivitas sehari-hari. Hal ini mungkin mengakibatkan setiap masyarakat akan menggunakan cara berbeda dalam menggunakan obat. Penelitian lain menyatakan penggunaan obat flu-batuk di masyarakat masih salah dalam memilih obat flu-batuk (36\%), karena tidak sesuai dengan keluha yang dialami (Lorensia et al., 2018). Hasil ini sejalan dengan penelitian yang menyatakan responden dalam menggunakan pengobatan usada dan juga medis dipengaruhi oleh konsep sehat dan sakit yang dimilikinya (Triyono et al., 2018). Hasil penelitian juga menyebutkan ketika masyarakat sakit tidak melakukan pengobatan sampai dirasakan cukup berat. Hal ini didukung oleh penelitian yang menyatakan responden tidak merasakan sakit atau keluhan yang parah responden tidak melakukan pengobatan untuk mengatasi keluhan yang 
dirasakan (Indriana \& Azinar, 2019). Oleh karena itu, pengobatan yang dicari dapat berakibat kondisi kesehatan menjadi lebih baik atau lebih buruk.

Persepsi sakit mengenai keluhan rasa sakit sama untuk setiap orang, masyarakat menjawab tidak setuju hanya seesar $32.4 \%$. Hal ini menunjukkan masyarakat masing menganggap setiap keluahan sakit adalah sama. Hal ini juga didukung oleh penelitian yang menyatakan masyarakat menganggap setiap keluhan pasti menggunakan obat yang sama.(Sridhar et al., 2017). Hasil penelitian lain juga menunjukkan indikator sikap, pengetahuan,dan perilaku, sikap masyarakat dalam memilih obat yang aman masih sangat rendah karena menganggap setiap keluhan sakit adalah sama (Siahaan et al., 2017). Pemahaman penggunaan obat rasional terutama dalam menggunakan cara pemakian dipengaruhi oleh faktor persepsi. Hal ini dibuktikan dari persepsi masyarakat mengenai keluhan akan mempengaruhi cara pemakian obat. Hal ini didukung oleh penelitian yang menunjukkan masyarakat yang sakit akan berusaha menggunakan antibiotik, walaupun tanpa resep dokter (Dewi et al., 2019).

Hasil penelitian menunjukkan kesalahan pengobatan yang paling tinggi adalah cara penggunaan obat terutama untuk obat dengan gejala yang tidak perlu diminum sampai habis. Hasil data penelitian menunjukkan masyarakat ketika mengalami sakit dan tidak bisa melakukan aktivitas, maka akan berusaha untuk menyembuhkan diri dengan berbagai cara pengobatan. Hasil ini sejalan dengan penelitian yang menyebutkan tingkat pengetahuan responden tentang swamedikasi obat batuk menunjukkan bahwa responden yang memiliki pengetahuan tinggi tentang swamedikasi obat batuk sebesar 40\% (Khuluqiyah et al., 2016). Hasil data pemahaman penggunaan obat rasional juga menemukan hasil pemahaman POR yang salah di masyarakat mengenai obat batuk, obat panas, obat diare tidak perlu diminum sampai habis jika gejalanya sudah hilang. Sehingga, hal ini menunjukkan menunjukkan terdapat perbedaan yang signifikan, mengenai persepsi sakit dengan pemahaman penggunaan obat rasional (POR). Hasil penenltian ini sesuai dengan penelitian yang menunjukkan persepsi membuat representasi emosional kepada pasien untuk menggunakan obat (Alluhayyan et al., 2020).

Sebagian besar masyarakat sudah paham dalam penggunaan obat harus menyesuaikan dengan kondisi pasien dan pasien tidak akan merahasiakan alergi obat yang dimiliki. Hal Ini menunjukkan masyarakat sudah mengetahui keamanan obat yang diminum dan melaporkan kejadian bila mengalami alergi. Hal ini sejalan dengan penelitian Persepsi masyarakat terhadap keamanan obat sangat tinggi 95,5\% dan bersikap positif terhadap obat sebesar 60,3\% (Syofyan et al., 2017). Penelitian lain yang juga mendukung menyatakan hanya $21 \%$ masyarakat belum memahami keamanan penggunaan obat (Norcahyanti et al., 2018). Hal ini disebabkan karena persepsi pasien mengenai sakit sangat memperhatikan kondisi tubuh agar dapat segera menjadi sehat.

\section{Kesimpulan}

Persepsi sakit memberikan pengaruh yang siginifikan terhadap pemahaman penggunaan obat rasional (POR). Kondisi tubuh terutama dalam hal tidak dapat melakukan aktivitas dan keluhan rasa sakit akan menyebabkan masyarakat mencari suatu pengobatan, sehingga hal ini dapat mengakibatkan pemahaman mengenai POR terutama mengenai gejala simtomatis dan penggunaan obat. Oleh 
karena itu, perlu pemberian informasi yang tepat tentang obat ketika masyarakat mencari pengobatan untuk mengatasi keluhan yang dialami.

\section{Ucapan Terima Kasih}

Ucapan terima kasih diberikan yang sebesar-besarnya kepada apoteker dan dokter yang sudah memberikan masukan dalam pembuatan kuesioner dan reviewer ya menyempurnakan artikel ini

\section{Daftar Pustaka}

Agustina, S. (2019). Persepsi Sakit, Pengetahuan dan Kepuasan dengan Pemanfaatan Pelayanan Kesehatan. Higeia Journal of Public Health Research and Development, 2(3), 274-285. Retrieved from http://journal.unnes.ac.id/sju/index.php/higeia\%0APersepsi

Alluhayyan, O. B., Alsahly, R. J., Aldawsari, A. A., Alghabawy, K. A., Alqaan, R. S., Almutairi, A. F., \& Alharbi, S. A. (2020). Illness perception and medication adherence among patients with primary hypothyroidism in al qassim, Saudi Arabia. Patient Preference and Adherence, 14, 1083-1092.

Amisim, A., Kusen, A. W. S., \& Mamosey, W. E. (2020). Persepsi Sakit Dan Sistem Pengobatan Tradisional Dan Modern Pada Orang Amungme (Studi Kasus Di Kecamatan Alama Kabupaten Mimika). Jurnal Holistik, 13(1), 1-18.

Arimbawa, P. E. (2017). Hubungan kepemilikan asuransi kesehatan dengan penggunaan obat rasional (POR) pada pasien swamedikasi. Medicamento, $4(2), 118-122$.

Arimbawa, P. E., \& Adi, I. P. G. P. (2019). Patient Perceptions On The Role Of A Pharmacist And The Understanding Of The Rational Use Of Medicines (RUM). Sustainability Science and Management, 14(6), 137-144.

Asmadi. (2008). Konsep Dasar Keperawatan. Jakarta: EGC.

Badan Penelitian dan Pengembangan Kesehatan. (2013). Riset Kesehatan Dasar (RISKESDAS) 2013. Laporan Nasional 2013, 1-384.

Dewi, siska P., Wardaniati, I., Pratiwi, D., \& Valzon, M. (2019). Sosialisasi Gerakan Masyarakat Cerdas Menggunakan Obat Di Desa Kumain Kecamatan Tandun Kabupaten Rokan Hulu. Jurnal Pengabdian Masyarakat Multidisiplin, 3(1), 55-61.

Hashemi, S., Nasrollah, A., \& Rajabi, M. (2013). Irrational antibiotic prescribing: a local issue or global concern? EXCLI, 12, 384-395.

Indriana, M., \& Azinar, M. (2019). Higeia Journal of Public Health Pencarian Pengobatan Krioterapi pada Wanita IVA Positif. 3(3), 479-491. Retrieved from http://journal.unnes.ac.id/sju/index.php/higeia

Khuluqiyah, I., Nurrahmah, N., Nourah, S., Fauziah, F., Shana, N., Aquila, F., Aulia, F., Rachmania, I., Syazwan, M., \& Dewi, K. (2016). Tingkat Pengetahuan Masyarakat Mengenai Penggunaan Obat Batuk Secara Swamedikasi. Jurnal Farmasi Komunitas, volume 3(No 2), 33-36.

Lorensia, A., Yudiarso, A., \& Arrahmah, R. (2018). Evaluasi Pengetahuan dan Persepsi Obat Batuk Swamedikasi oleh Perokok. Media Kesehatan Masyarakat Indonesia, 14(4), 395. 
Lorensia, A., Yulia, R., \& Wahyuningtyas, I. S. (2017). Hubungan Persepsi Penyakit (Illness Perception) dengan Kontrol Gejala Asma pada Pasien Rawat Jalan. MPI (Media Pharmaceutica Indonesiana), 1(2), 92-99.

Miyazaki, M., Nakashima, A., Nakamura, Y., Sakamoto, Y., Matsuo, K., Goto, M., Uchiyama, M., Okamura, K., Mitsutake, R., Urata, H., Kamimura, H., \& Imakyure, O. (2018). Association between medication adherence and illness perceptions in atrial fibrillation patients treated with direct oral anticoagulants: An observational cross-sectional pilot study. PLoS ONE, 13(9), 1-13.

Nofiyanto, E., Utami, E. W., Koeswo, M., Malang, P. N., Sakit, R., Daerah, U., Waluyo, N., Kabupaten, W., Magister, P., Rumah, M., Fakultas, S., Universitas, K., \& Malang, B. (2014). Perbedaan Persepsi Sehat-sakit Pasien Menjadi Alasan Utama Kejadian Pulang Paksa Illness Perception Difference is the Major Reason of Discharge against Medical Advice. Jurnal Kedokteran Brawijaya, 28(1), 114-118.

Norcahyanti, I., Nugraha Widhi Pratama, A., \& Asfarina, H. (2018). Survei Tingkat Pengetahuan tentang Keamanan Penggunaan Obat pada lbu Menyusui di Puskesmas Sumbersari Kabupaten Jember. Pharmaceutical Journal of Indonesia, 3(2), 65-74.

Ruksakulpiwat, S., Liu, Z., Yue, S., \& Fan, Y. (2020). The association among medication beliefs, perception of illness and medication adherence in ischemic stroke patients: A cross-sectional study in China. Patient Preference and Adherence, 14, 235-247.

Shah, K., Halder, S., \& Haider, S. S. (2021). Assessment of knowledge, perception, and awareness about self-medication practices among university students in Nepal. Heliyon, 7(1), e05976.

Siahaan, S. A. S., Usia, T., Pujiati, S., Tarigan, I. U., Murhandini, S., Isfandari, S., \& Tiurdinawati, T. (2017). Pengetahuan, Sikap, dan Perilaku Masyarakat dalam Memilih Obat yang Aman di Tiga Provinsi di Indonesia. Jurnal Kefarmasian Indonesia, 7(2), 136-145.

Sridhar, S. B., Shariff, A., Halabi, N. Al, Sarmini, R., \& Harb, L. A. (2017). ssessment of Perception, Experience, and Information-seeking Behavior of the Public of Ras Al-Khaimah, United Arab Emirates, Toward Usage and Safety of Complementary and Alternative Medicine. J Pharm Bioallied, 9, 4855.

Syofyan, Ghiffari, H. D., \& Erizal Zaini. (2017). Persepsi, pengetahuan, dan sikap tentang obat pada siswa sekolah menengah atas (SMA) di Kota Pariaman, Sumatera Barat. Jurnal Sains Farmasi \& Klinis, 4(2), 83-87.

Triyono, K., Dwi, S., \& Yohanes, K. H. (2018). Konsep Sehat Dan Sakit Pada Individu Dengan Urolithiasis (Kencing Batu) Di Kabupaten Klungkung, Bali. Jurnal Psikologi Udayana, 4(02), 263.

WHO. (2002). Promoting Rational Use of Medicines: Core Components. 6. Retrieved from http://apps.who.int/medicinedocs/pdf/h3011e/h3011e.pdf 